\title{
Online tutoring procedure for research project supervision: management, organization and key elements
}

\author{
Antònia Darder Mesquida ${ }^{*}$, Adolfina Pérez Garcias² \\ ${ }^{1}$ University of the Balearic Islands, Department of Applied Pedagogy and Psychology of Education, Spain \\ \{antonia.darder@uib.es\} (D) \\ ${ }^{2}$ University of the Balearic Islands, Department of Applied Pedagogy and Psychology of Education, Spain \\ \{fina.perez@uib.es\} (iD
}

Received on 2 November 2014; revised on 2 November 2014; accepted on 17 November 2014; in press on 15 April 2015; published on 15 July 2015

DOI: 10.7821/naer.2015.4.110

\begin{abstract}
Research project tutoring appears as a crucial element for teaching; it is a planned action based on the relationship between a tutor and a student. This paper presents the findings of a design and development research which has as its main aim to create an organization system for the tutoring of online research projects. That system seeks to facilitate the tutoring and supervision task with trainee researchers, providing guidance for its management and instruments for its implementation. The main conclusions arising from this research derive from considering the need to offer a solution to the problem of distance research project supervision and has materialized in organization and sequencing through a model about the variables that influence the research project tutoring problem.
\end{abstract}

KEYWORDS: SUPERVISION, DIRECTOR-SUPERVISEE, RELATIONSHIP, RESEARCH PROJECT, GUIDANCE

\section{INTRODUCTION}

The aim sought with the research presented in this paper is to design a procedure for online research project tutoring (Spanish initials, TPI), identifying the organizational and process-related elements in practice and offering solutions to it. TPI is understood here as the organization (management) of research project supervision and the relationship which is established between the supervisor and the trainee researcher. The research works revised describe this tutoring with the terms 'supervision' or 'direction.' Taking into account that a tutor represents support, guidance and orientation, that different types of tutoring exist depending on their purpose -pedagogic, administrative, personal, practicum-related, etc.- and also that a supervisor performs pedagogic roles focused on research, leads us to believe that it is possible to refer to research project direction/supervision as a special case of tutoring that offers the student guidance and orientation in aspects linked to the acquisition of research skills, motivation and personal orientation, administrative advice, and technological as well as professional issues.
An iterative methodological process is followed that includes a variety of design, implementation, assessment, and redesign stages. That process entails: a) the design of a procedure for TPI based on a review of the literature and the collaboration of potential users; b) the consultation with research project tutors who have experience in online supervision, and with trainee researchers, about the procedures, actions and factors that influence tutoring; c) implementation and putting into practice of the tutoring model with a group of tutors and trainee researchers; d) assessment and improvement. These actions are developed cyclically and, therefore, the design progresses, improves, and matures according to the results which are progressively obtained.

The research developed here is placed within the framework of the actions undertaken in the project Estrategias metodológicas para la integración de entornos virtuales institucionales, sociales y personales de aprendizaje [Methodological strategies for the integration of virtual, institutional, social and personal learning environments], with the official code EDU2011-25499 of the Educational Technology Group at the University of the Balearic Islands.

Its development is additionally contextualized in a specific institution and degree, the National Southern Patagonia University (Spanish initials, UNPA) and the Master's Degree in Education in Virtual Environments.

The present paper shows a model for online TPI where its key elements and the links existing between them are identified.

\section{REFERENCE FRAMEWORK}

A research-oriented post-graduate program has as its essential aim to train researchers, and it consequently requires an in-depth knowledge of a specific subject (Angarita \& Mateo, 2011). Its aim is therefore to provide training to future professionals in the research practice. These studies must pursue theoretical, methodological, and epistemological training and, accordingly, trainee researchers need to obtain skills and be able to "comprehensively explain and understand the problems of a complex and dynamic reality in its development” (Angarita \& Mateo, 2011, pp. 153).

For Gurr (2001), a research development process has to produce autonomous researchers who not only are aware of the legislation and the expectations inside their discipline but also 
can assess their own plans and actions with a view to ensure their compliance.

The purpose of any supervision process has to focus on the aim of making it easier for the student to become an independent professional researcher. The pedagogy related to research project supervision has traditionally been associated with a one-to-one (tutor-trainee researcher) supervision model (Lee \& Green, 2009) where the tutor supervises and the student carries out the research tasks. These models imply that the tutor is able to provide the support needed for the successful completion of the research project. This means a change within the pedagogic process with regard to the efforts carried out between the tutor and the trainee researcher towards collaborative work (Amundsen \& McAlpine, 2009)

In turn, Holley and Lee (2012) highlight that PhD students' satisfaction increases when they have a significant relationship with their tutor. Similarly, Hilmer and Hilmer (2011) claim that the success of a research project largely depends on the tutor who supervises the research and the study program where it belongs.

As for contents and research, the current Spanish legislation refers to the coach figure using the expression 'research project supervisor,' distinguishing it from the tutor figure, who is given a role linked to personal and bureaucratic support as well as to the interaction of the trainee researcher with the academic board that will assign a supervisor to him. Sometimes both roles are assumed by the same person, though.

Zeegers and Barron (2012) defend the need for change in TPI processes towards a systematic and organized pedagogy where tutors promote change, work with their students helping them develop the skills that they need, and build true practice and learning communities (Shacham \& Od-Cohen, 2009). Tutoring processes must include dialogue with the trainee researcher and promotion of relationships with other researchers and experts. Thus, Jaeger, Sandmann and Kim (2011) highlight the need to create learning communities in their study with tutors and trainee researchers. Both tutors and students have to build communities where information is shared about program requirements and where dialogue, as well as interaction and collaboration, are encouraged. This interaction between partners increases the feeling of membership and removes the feeling of isolation and disorientation which can arise at times within the context of online education (Sánchez \& Castellanos, 2013).

Green \& Bowden (2012) value the introduction of support given by other tutors, which additionally means a commitment to the training of less-experienced tutors. These same authors propose a TPI model which bears in mind that this is a process with an intellectual, emotional, social and physical scope (the latter in the sense that it becomes important to hold periodical meetings with the trainee researcher).

Overall, Deane and Peterson (2011) define as one of the most important challenges for TPI that tutors should provide enough orientation for students to acquire research skills without failing to give the student sufficient autonomy to become an independent researcher.

According to Blass, Jasman and Levy (2012), the TPI practice is a personal issue; tutors must have as their main concern to find ways to help and guide their students throughout the research project development process (Gardner, 2009); this acquires great importance when it comes to the orientation and skills that a student needs to acquire during the work carried out with the tutor (Hernández \& Díaz, 2010) and the implementation of the research project.
Furthermore, interaction and communication with the research project tutor as well as with other trainee researchers and the tutor's research group, amongst others, becomes one of the key elements to overcome the feeling of isolation when studies are taken in a virtual format. This means incorporating studentcentered methodologies through the creation of environments that reflect more open and flexible approaches (Salinas, 2009).

\section{RESEARCH METHODOLOGY}

The methodological design developed in the present paper is placed within the framework of design and development research. A decision was made to follow the development research stages proposed by McKenney and Reeves (2012) in a mixed way: analysis-exploration, design-construction, assessment-reflections, with implementation in parallel, and maturity of intervention as well as of theoretical comprehension as a result. It all consecutively and in the form of continuous cycles aimed at improving this practice.

Research development is carried out through case studies at a small scale: a) action research in the collaborative building of the procedure with the aim of organizing the elements that shape TPI and solving a particular problem with a specific group (Reeves, McKenney, \& Herrington, 2011); b) consultation with trainee researchers and with tutors that have experience in the supervision of online research projects, seeking to carry out rigorous and reflective research on the research problem; c) the implementation and assessment of the procedure.

This matches what Plomp (2013) defines as research based on design for education: it deals with complex problems associated with the educational practice. The research process adapts to the approach of being repercussive (iterative) and reflexive (McKenney \& Visscher-Voerman, 2013). It implies the need for interaction with participants for the purpose of clarifying problems and suggesting possible solutions (van den Akker, 2013). In this case, both the potential users and the experts take part in the process of design, revision and reformulation of the tutoring procedure under study.

The study was performed with a group of potential tutors from the National Southern Patagonia Master's Degree; a group of tutors with a broad experience in online TPI and their respective trainee researchers; and a group of trainee researchers.

The methodological display has as its aim to bring together a variety of data and information with different techniques about the same topic and from various points of view: the procedure to organize online tutoring for research project supervision with the aim of performing a triangulation meant to increase data analysis quality (Plomp, 2013).

\subsection{Aims}

The overall aim of this research is to design and develop a procedure for the tutoring of online research projects, offering solutions in practice and identifying its organizational and process-related elements.

This aim can be broken down into several specific aims:

(1) To identify, analyze and organize the elements that shape research project tutoring

(2) To identify and assess the trainee researcher's needs in the process along with the tutor's profiles

(3) Implementing and assessing the procedure for TPI 


\subsection{Research stages and structure}

The research process is carried out from 4 design and development stages: 1) situation analysis and literature review; 2) design and development of solutions; 3) implementation, assessment and production of documents; and 4) product adjustments. The completion of these stages is represented cyclically taking as a reference the design and development stages presented by McKenney and Reeves (2012). It materializes in the following figure (1), where the research structure is summarized.

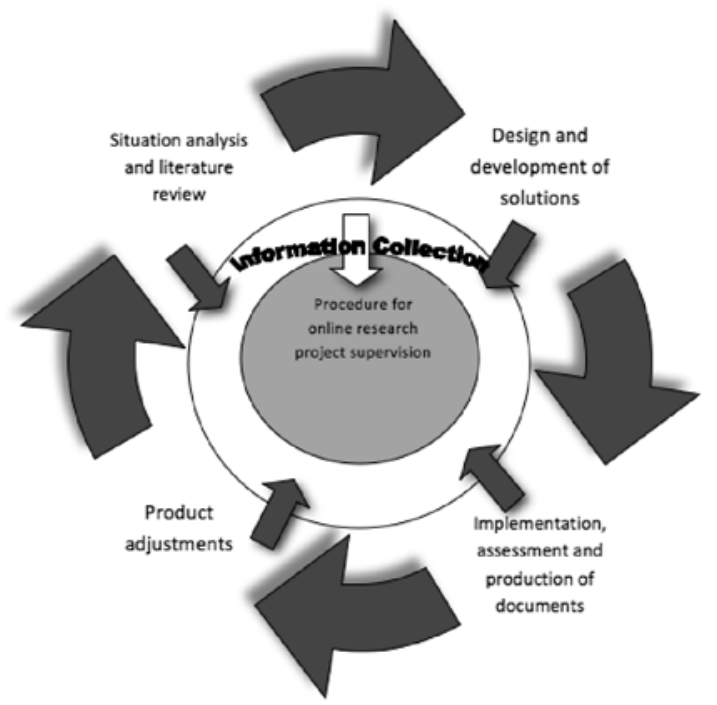

Figure 1. Research process stages (adapted from McKenney \& Reeves, 2012)

1. Situation analysis and literature review. This stage defines the need to design a TPI procedure for the purpose of offering solutions for this practice. The context where the research takes place is described and analyzed together with a systematic review of the literature, identifying, analyzing and organizing the elements that shape TPI. The literature review will not only provide a conceptual framework about the problem to be treated but also will serve as the basis to design the first prototype, since this will permit to identify the main elements of tutoring (aim 1), so that they can be made available to the group of research project tutors and subject to their collaborative discussion and re-construction.

2. Design and development of solutions. Different studies are designed for its completion:

a) Creation of a work group formed by potential tutors at the institution for the purpose of building the TPI procedure collaboratively. In turn, an effort is made to obtain information about the tutor's experience to complete and reorganize the procedure on the basis of that information. Therefore, the collaborative work group is established as a technique to search for -and collect-information. The lines of work from which our research starts and on which it is our intention to explore with tutors through the different collaborative work proposals are: a) the tutor figure; b) the tutor's functions; c) the student's support and socialization relationship; d) the virtual work environment; and e) the work procedures and the implementation. The instrument selected to collect information is the observation card.
In order to create this collaborative work group, the Institution made a selection among lecturers of the Master's Degree who were supervising research projects or who were expected to supervise them at the time; 6 of them started their participation in the work group.

b) A discussion group with students of the UNPA Master's Degree to collect information about the needs of trainee researchers through open-ended questions: Can research project supervision be considered a case of tutoring? As research project students -or future students- which characteristics of tutors do you regard as desirable? What are your needs as students in this field? Is it possible to do this tutoring virtually? Which tools will you need to carry it out?

This discussion group was planned taking into account where it developed, in this case, the seminar of the UNPA Master's Degree in Education in Virtual Environments about Teaching Tutoring in Virtual Teaching and Learning Environments during the academic year 2012-13. Three out of nine people registered for that seminar took part in the discussion group.

c) Consultation with tutors who have experience in online research project supervision and one of their students for the purpose of studying the relationships between a tutor and a trainee researcher. The collection of information is carried out using a semi-structured interview and closed questions from a questionnaire.

During this consultation process, an invitation was made to 23 supervisors from $16 \mathrm{PhD}$ programs in education at different institutions which had students enrolled doing their research in places located far from the institution in question, and a total of 14 interviews was finally achieved. Each one of these supervisors was asked to provide the contact of one or two students who had recently completed their research work and whose doctoral thesis had been defended between 2010 and 2012 -which eventually allowed us to interview 12 students.

The categories for data analysis were established from notes about the interviews taken on the spot which were subsequently applied to the transcription of interviews. The themes established for information collection are: expected qualities of a research project supervisor, research project supervision styles, tutors' view about research project supervision, tutors' perception about their role in tutoring, advantages of creating tutoring teams, type of assistance or feedback that is given to students, skills that trainee researchers have or lack at the beginning of the postgraduate program and the ones that they have acquired when the program comes to an end, and procedures applied during research project supervision which induce student intellectual growth.

3. Implementation, evaluation and production of documents. This stage includes the development of a case study about the implementation of the TPI procedure designed on the basis of the data extracted from the literature review, from the work group with potential tutors, from the discussion group with trainee researchers, and from the consultation with experienced tutors and students with a tutor-trainee researcher pair from the UNPA Master's Degree. The aim sought was for tutors (with their students) to organize the virtual environment for tutoring 
through the tool selected by the institution -Mahara in this case. It is worth highlighting that, out of 9 potential tutors, it was only possible to have a tutor-trainee researcher pair.

The information is collected through an observation card and a questionnaire focused on the following topics: the online TPI environment; the selected tool: Mahara, the support and socialization both of the tutor and of the student; and the working procedure applied. The questionnaire collects the same information as the one carried out with experienced tutors, adding the designed and implemented TPI model and the virtual communities created within the tool.

4. Procedure adjustments. TPI procedure adjustment. Analyzing the results obtained in each one of the studies leads to the creation of principles for the design of tutoring procedures and a reference guide for the planning and organization of actions that could prove valid for TPI. Information-gathering instruments.

The combination of work and information collection in this study results in an online TPI procedure which adopts the form a conceptual map with the ultimate aim of making it easier to understand the aforesaid procedure and to navigate through it (Darder, Pérez, \& Salinas, 2012, 2014).

\section{RESULT DISCUSSION}

The results are presented from the elements which have some bearing on the online TPI procedure. This TPI model is the result of all the design and development stages in this research and, therefore, of the information collected with regard to the systematic literature review, of the work group for the collaborative construction of this procedure, of the virtual discussion group with trainee researchers, of the consultation with pairs of tutors and trainee researchers during the final stage of the project, and with tutors who had experience in online supervision, and of the actual implementation of this procedure. All the results were integrated into the TPI model which is represented by means of a conceptual map for the purpose of facilitating the comprehension of this procedure as well as the navigation through its contents, identifying:

TPI elements: the research project tutor (skills, supervision styles and functions); the trainee researcher, his/her needs and the skills that they need to assimilate; and the support and interaction both between them and with the other partners.

The elements that influence a research project when it comes to achieving success and the elements which are necessary in a virtual environment for TPI.

çAdvisable working patterns and processes for the tasks performed both by the tutor and the student and for the achievement of a positive relationship between them. The protocols and instruments required to monitor the trainee researcher during this process: a student's initial card; a student's follow-up card; and guidelines to keep a work diary.

Below can be seen the aforementioned conceptual map (Figure 2), the key concepts of which have the resources needed for this TPI procedure associated with them.

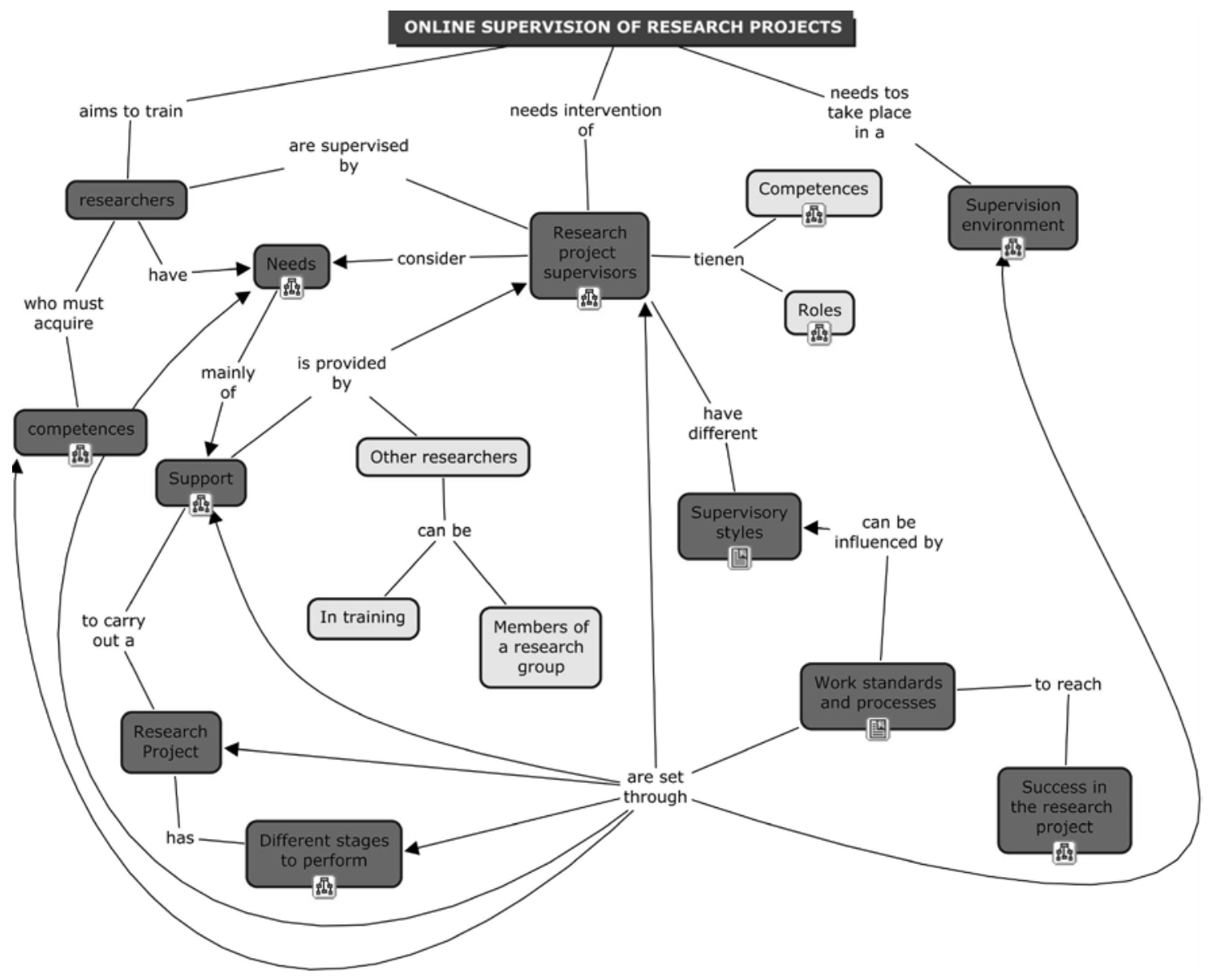

Figure 2. TPI process final version: representation in the form of a conceptual map 
To see the published map and to interact and navigate through it, and also to be able to observe the identified elements in a developed form, you can visit the following URL: http://mc142.uib.es:8080/rid=1LWKPDWLX-29GTTBD-

3QF/MMCC_tutor_projectes.cmap

Let us now see in greater detail the elements presented through the concepts included in this online TPI system.

The tutor figure: the conceptual map's evolution denotes the importance given to it, both in research and in the work with potential tutors, going from an initial review of the literature, where this figure was placed at the background, highlighting only the organization of tutoring and the socialization of students. Thus, as a final outcome, attention is paid to the tutor's supervision skills, functions and styles, and a modification is made in the tutor figure (Figure 3) adding desirable features to it.

The tutor's qualities. The results obtained from the consultation with trainee researchers and tutors with regard to the characteristics that define a research project supervisor are: accessibility, empathy, friendliness, support, organization, an open mind, mastery of the field, mastery of methodology, direction, etc.

Table 1. Results about the desirable characteristics for a research project supervisor (semi-structured interview and closed questions)

\begin{tabular}{llll}
\hline & \% Tutors & $\begin{array}{l}\text { \% Trainee } \\
\text { researchers }\end{array}$ & \% Total \\
\cline { 2 - 4 } & & 66.67 & 50 \\
$\begin{array}{llll}\text { Accessible, friendly, empathet- } \\
\text { ic }\end{array}$ & 35.71 & 50 & 61.54 \\
Showing a supportive attitude & 71.43 & 16.67 & 11.54 \\
Having an open mind & 7.14 & 41.67 & 46.15 \\
Being organized & 50 & 58.33 & 57.69 \\
Mastering the research field & 57.14 & 25 & 23.08 \\
Mastering the methodology & 21.43 & 58.33 & 53.85 \\
Being directive & 50 & 8.33 & 7.69 \\
Others & 7.14 & & \\
\hline
\end{tabular}

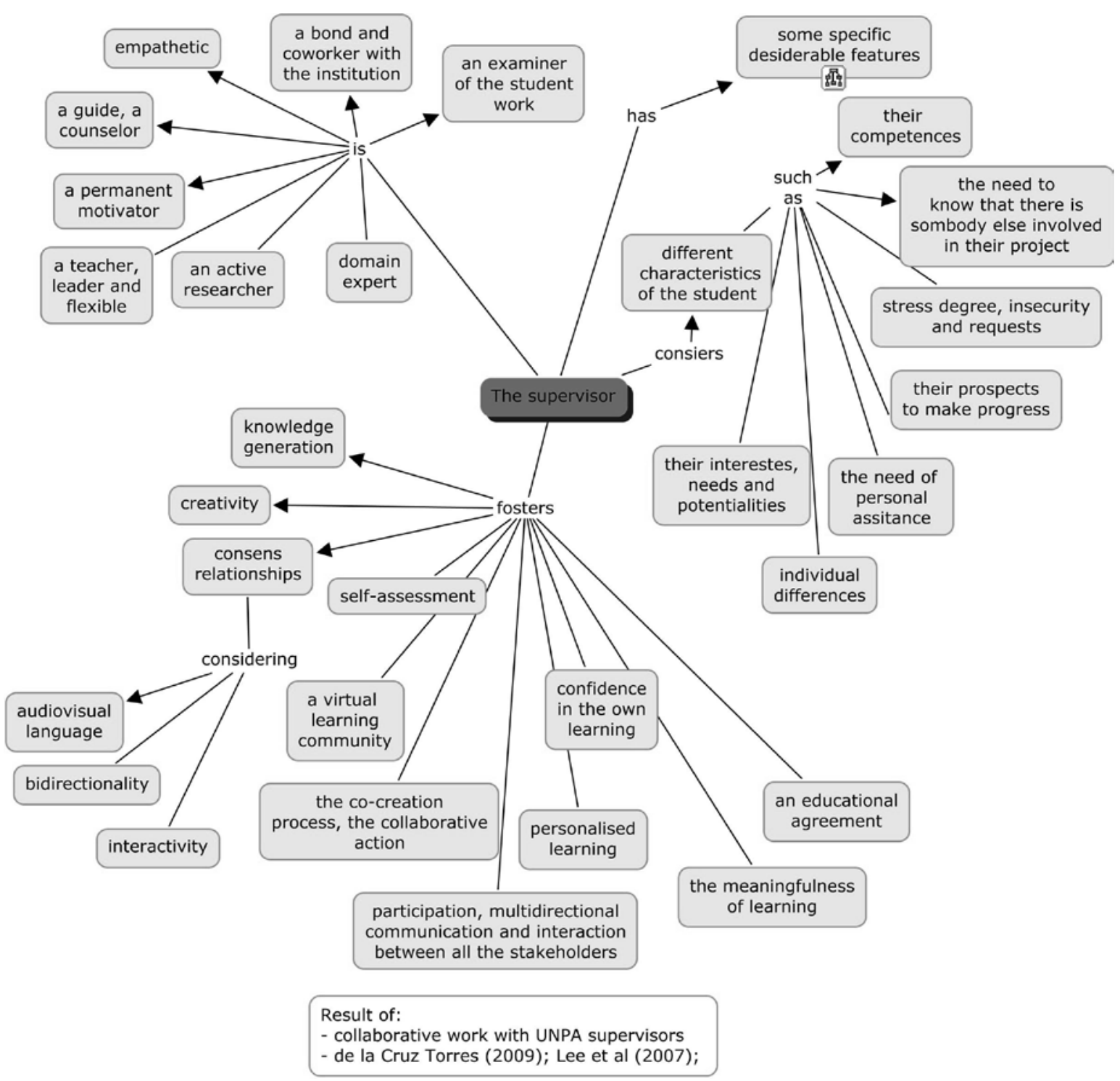

Figure 3. The reseach project tutor figure http://mc142.uib.es:8080/rid=1LWKPDWLX-67WSDH-3QK/figura_tutor.cmap 


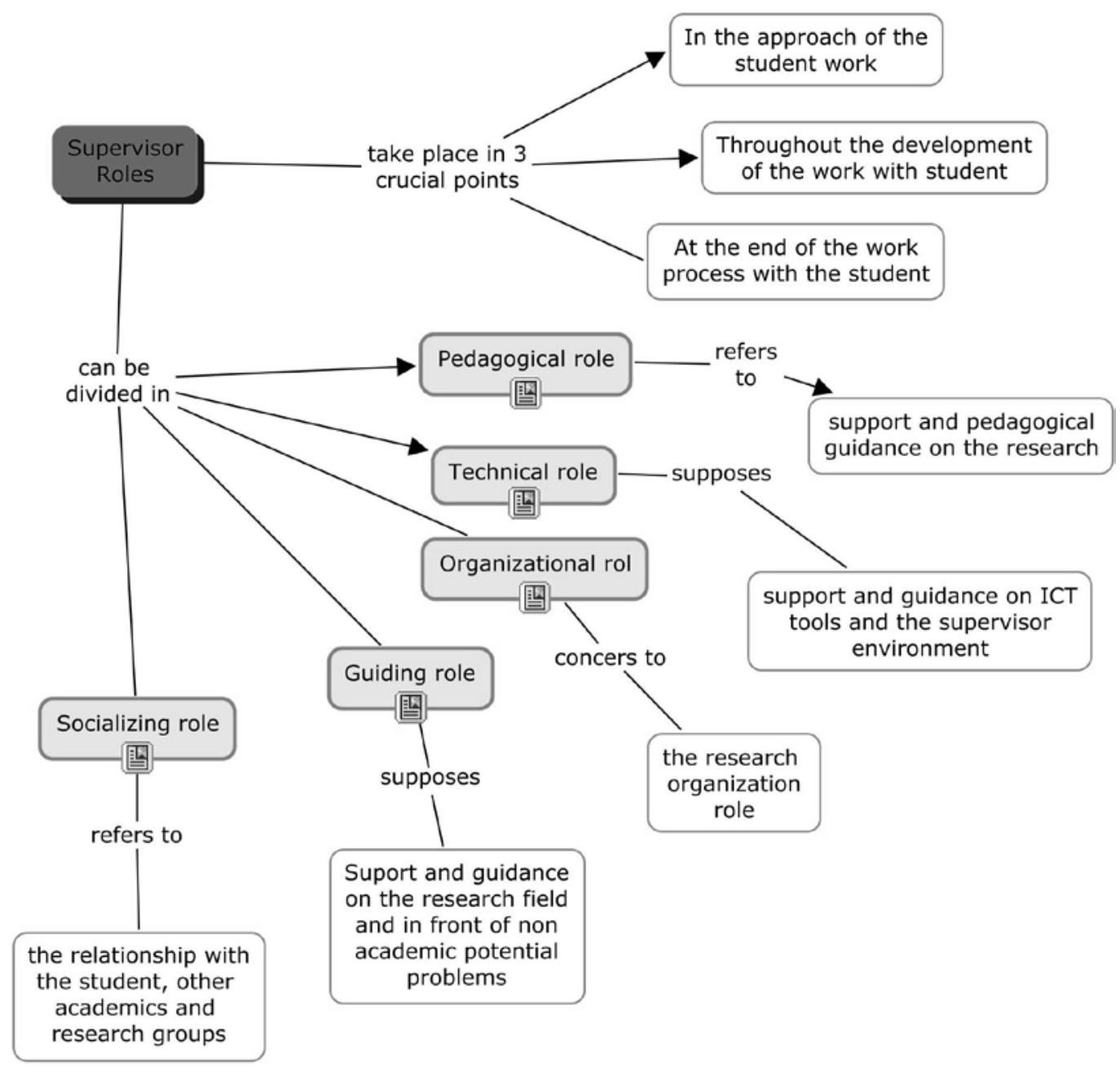

Figure 4. The research project supervisor's roles http://mc142.uib.es:8080/rid=1LWKPDWLX-8LPNZ0-3QJ/funciones.cmap

The tutor's functions. The result of an evolution from the literature review to the collaborative work carried out with the group becomes visible here: the functions attributed to tutors have increased in number; they are distributed according to the character and the moment in which they are displayed, and a high degree of specification is achieved as shown in Figure 4. One can see the vision of tutors about their role in TPI as formation or training in research; it is worth highlighting that all tutors believe that they provide training to trainee researchers.

The supervision styles of a research project tutor: five distinct styles differentiated by two axes can be observed: the degree of supervision control projected by the supervisor over the student and the degree of support that the latter receives from the former. Four other styles are similarly suggested which complement these five styles, in order to make it possible to identify the different procedures and attitudes that a research project tutor may adopt and, bearing in mind that these are not closed styles, since the supervisor will adopt one style or another depending on the trainee researcher's needs as far as training is concerned, and on each specific context. According to the studies performed about research project supervision styles (Brown \& Atkins, 1988; Gatfield, 2005; Gurr, 2001; Lee, 2007 \& 2008; Mainhard, van der Rijst, van Tartwijk \& Wubbels, 2009; Vilkinas \& Cartan, 2001; Vilkinas, 2007) they can be summarized as follows:
Table 2. Supervision styles

\begin{tabular}{|c|c|c|}
\hline Style & & Style \\
\hline $\begin{array}{l}\text { Encourages collabo- } \\
\text { rative work } \\
\text { Provides freedom }\end{array}$ & $\begin{array}{l}\text { They may adopt any of } \\
\text { the following procedures }\end{array}$ & $\begin{array}{l}\text { Encourages criti- } \\
\text { cal thinking } \\
\text { Helpful (makes } \\
\text { things easier) }\end{array}$ \\
\hline Passive & & Personal support \\
\hline Directive & & Innovative \\
\hline Integration-oriented & & \\
\hline
\end{tabular}

The support and socialization relationship: our starting point was the 5 socialization moments described by Salmon (2012) and, although they have been regarded as highly important among TPI procedure elements, a decision based on the collaborative work with the group of tutors was made to add the specific relationship between the actors: the tutor and the trainee researcher (Sánchez, Manzano, Rísquez, \& Suárez, 2011), between researchers, and between tutors.

Within the context of the web 2.0 it is important to boost participation, multidirectional communication and interaction between all the actors involved encouraging the creation of a 'virtual learning community' with regard to which each student has a feeling of 
membership; being ready to generate an effective dialogue with participants and between participants, thus favoring the construction of cooperative and collaborative work. (Tutor 3 , written in the activity forum, 04/03/12)

The trainee researcher. The evolution suffered by the TPI procedure through the different cases studied is added to the initial work lines, the trainee researcher. The latter had not been taken into account, but he becomes highly relevant in the light of the skills that he/she needs to acquire during the work with the tutor and while the research project is being carried out, as well as the need for support and contact with the tutor, with researchers, and with other students.

The trainee researcher's needs, which have to be considered for the research project to be successfully completed, will depend on the trainee researcher; however, a general overview is presented of the needs detected by other research works and by the results of the discussion group (forum) with trainee researchers, as can be seen in the following figure.

Working procedures and implementation. They have evolved from an initial version -which only took into account the stages in a research project- to a final version which completes those stages with work patterns both for the tutor and for the student, as well as the action and implementation, relating it to virtual tutoring environments. These stages can be understood as gradual phases that will help to build the research project. The same as in the paper by Ewing, Mathieson, Alexander and Leafman (2012), it is explained that the planning and execution of a research project poses huge challenges for many trainee researchers -and these challenges may be made even bigger by the students taking the online post-graduate program. That is why a model is developed for a $\mathrm{PhD}$ program characterized by suggesting a highly structured and sequenced curriculum, thus facilitating dialogue, collaborative learning, and an assessment based on research skills performance. Such a program guides students through a series of progressive research stages.

In turn, student follow-up instruments have been designed and developed which must be taken into account both in the work patterns and processes and in the virtual tutoring environment. These instruments are: student's initial card, follow-up card, and work diary.

Student's initial card or personal data, to be handed in when tutoring starts so that the tutor can have some basic information about the student.

Student's follow-up card; this card is used by the tutor during the sessions with the student, and it can be kept together with the student's data and files; it will thus collect all the agreements as well as the tasks performed with the student during these sessions. Attention is paid here to the student's general data, to the first session, to the subsequent sessions held in the course of the research project, and to the final sessions.

Work diary; it is developed by the student, and sharing it with the tutor allows trainee researchers to gradually describe their work and progress by means of a diary -thanks to this, the diary can also serve as a monitoring instrument for the tutor. A record is kept in this diary of the progress made by the trainee researcher, both on his/her own and through the agreements and planning carried out with the supervisor. The possibility exists to use it as a port-folio -a tool which is highly suitable to show the student's achievements and learning (Le, 2012).

All the instruments are developed in the form of a 'card,' and their contents are gradually described for the purpose of making both the tutor's work and that carried out by the student easier.

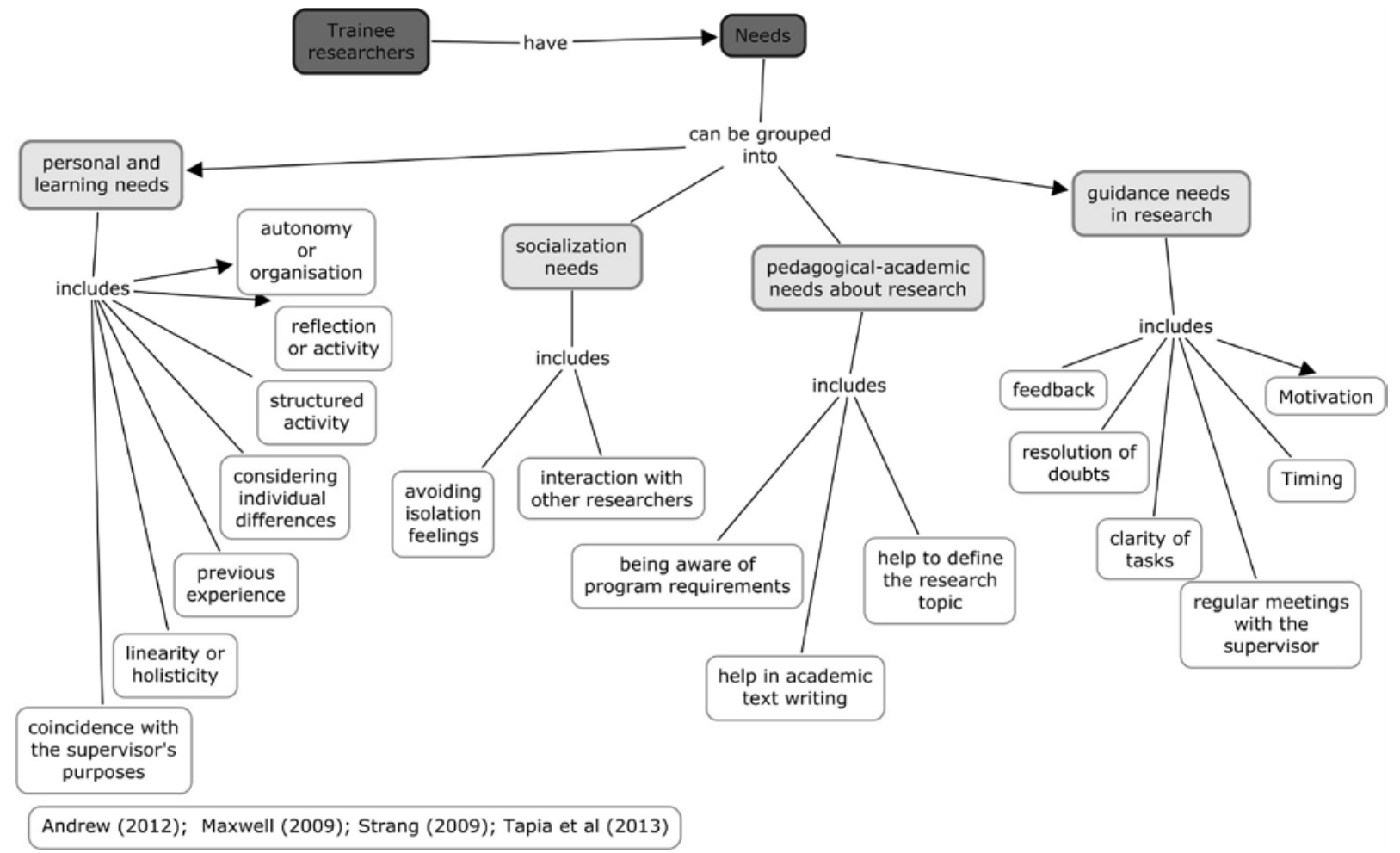

Figure 5. The trainee researcher's needs 
They may also reach an agreement to use another instrument to collect this information. Both these instruments and the working procedure developed in the form of a guide can be consulted in the TPI model.

One element which needs to be borne in mind and which has close links with work procedures is research project success where the elements that need to be considered in order to reach success are described. These include, amongst others: reasons; research project tutor; research theme; access to a research group; publication of results; or the study program.

The Virtual Working Environment. The procedure incorporates different tools which can be used in TPI. As for the adaptation of the tool and the working environments through groups as it was presented in the activity, the views expressed by potential tutors turned out to be positive too, assessing the tool as a powerful one for TPI.

In relation to this TPI procedure, it is worth stressing that the opinion of the two people who put that procedure into practice was highly positive, assessing it as: "an excellent piece of work which guides, clarifies, and specifies a suitable itinerary to guarantee success when monitoring and accompanying a thesis candidate. It presents an axiological component par excellence, since it faces the tutor with a clear, precise, and complete line of work, considering all the possible dimensions which need to be borne in mind, something that people are not used to doing. It is realistic, possible and perfectly attainable" (Answer to the tutor's open-ended questionnaire).

\section{CONCLUSIONS}

One of the first conclusions drawn from the present work refers to the fact that research project supervision can be referred to as a special case of tutoring, insofar as the texts reviewed show authors using the word 'tutor' and 'supervisor' interchangeably. This is also reflected in Royal Decree 99/2011, of January 28th, whereby the official $\mathrm{PhD}$ studies are regulated. Although this decree distinguishes the tutor figure from that of the supervisor, it does specify as well that these two figures often coincide in the same person.

The general aim of our study, to design and develop a procedure for online TPI offering solutions in practice and identifying its organizational and process-related elements, is reflected on the TPI procedure developed and reinforced by the results of this study.

The need to offer a solution to the problem of organizing and managing online TPI has materialized in organization and sequencing through a model about the variables that influence the research project tutoring process. In our view, this can make an important contribution to post-graduate studies, to research project tutors and to researchers' training, since it has as its aim to make the tutoring task easier and to help both trainee researchers and tutors to achieve project success and to favor a good relationship between them.

Therefore, a description and a definition have been given, not only of the actors who take part in this type of tutoring but also of the skills that each one of them must acquire. It is our conviction that the organization and guidance processes are reflected as well, along with the relationship that needs to exist between both actors, it all for the purpose of achieving the ultimate aim, to carry out a successful research project.

More precisely, the tutor figure seems to us one of the key elements in this virtual research project tutoring system, the description of which is widely reflected on its desirable characteristics, the skills and roles that the tutor has to develop and the research project supervision profiles or styles.

The specific aims of our research work can thus be regarded as successfully developed, namely:

(1) The elements that shape research project tutoring are identified, analyzed and organized.

(2) The trainee researcher's needs in the process, as well as the tutor's profiles, are identified and assessed.

(3) The TPI procedure is implemented and evaluated.

A number of valid procedure policies to reach success within a research project concerning collaborative work strategies between the supervisor and the trainee researcher have consequently been identified, along with the instruments and tools that make the research project supervision process easier.

The results obtained in the present research have revealed a consensus on the fact that the student-tutor relationship suffices for the former -though it is not advisable. The student needs to mix with other peers that find themselves in the same situation because this favors information exchange as well as communication, and it also causes loneliness to disappear, it enriches work and provides motivation. Virtual communities make it easier to achieve this, which represents an important solution to this need in our opinion. Similarly, it is our conviction that a research and the student-tutor relationship may become richer if the consideration of the supervisor as an isolated individual is left aside and virtual communities of research project tutors are created within institutions that allow them both not only to share experiences and information but also to interact and support one another.

Taking into account the present-day immersion in an educational innovation process through ICT use, even though the UNPA research project tutors were given a chance to participate in the research project tutoring procedure construction, probably the lack of the motivation, the skills and the vision required, or the shortage of time and resources (Tejedor, García-Valcárcel, \& Prada, 2009) for the project resulted in the loss of participants, insofar as a change within the academic environment may sometimes be seen as additional and unnecessary work (Rodríguez, 2011)

In this respect, ICT development suggests a reformulation of the whole educational system (Correa \& de Pablos, 2009) and, in this particular case, a proposal is made to reformulate the tutoring system leaving behind the traditional perspective and moving towards another perspective where collaboration can be implemented using the potentialities offered by information and communication technologies. That is why distance TPI and the development of this procedure means an innovation process which has as its aim to find both individual and social solutions, thus enabling students and tutors to participate in virtual learning communities and improving interaction quality and effectiveness through the utilization of ICT tools, and supporting this collaborative learning process (Salinas, 2010).

This research project tutoring procedure, as well as all the products designed and derived from it, namely: organization of research project tutoring as a procedure; organization and management of the virtual environment where this procedure can take place; creation of virtual learning communities both for trainee researchers and for tutors; guidance offered by work development patterns and processes; and student follow-up instruments (the student's initial card, the follow-up card, and the work diary) represent the contribution made with this 
research paper -which can be thoroughly consulted at the URL provided in the results section. These products can in turn become a useful source of guidance and support for online research project tutors, although it must be remembered that our study is placed within the context of education sciences and, therefore, another possible line of research could consist in identifying the specific modifications and/or adaptations that would have to be made for their application to any field of knowledge.

\section{REFERENCES}

Amundsen, C., \& McAlpine, L. (2009). "Learning supervision”: trial by fire. Innovations in Education and Teaching International, 46(3), 331-342. doi:10.1080/14703290903068805

Andrew, M. (2012). Supervising doctorates at a distance: three trans-Tasman stories. Quality Assurance in Education, 20(1), 42-53. doi:10.1108/09684881211198239

Angarita, J. L., \& Mateo, M. C. (2011). The challenge of undertaking a PhD: PhD models and doctoral thesis. Orbis. Revista Científica Ciencias Humanas, 7(20), 149-177. Retrieved from http://www.revistaorbis.org.ve/pdf/20/art6.pdf

Blass, E., Jasman, A., \& Levy, R. (2012). Supervisor reflections on developing doctoralness in practice-based doctoral students. Quality Assurance in Education, 20(1), 31-41. doi:10.1108/09684881211198220

Brown, G., \& Atkins, M. (1988). Effective Teaching in Higher Education. London: Methuen. doi: 10.4324/9780203221365

Correa, J. M., \& de Pablos, J. (2009). Nuevas Tecnologías e Innovación Educativa. Revista de Psicodidáctica, 14(1), 133-145. doi:10.1387/RevPsicodidact.255

Darder, A., Pérez, A., \& Salinas, J. (2012). El mapa conceptual como instrumento de investigación: construcción y representación de un modelo de tutoría virtual. In A. J. Cañas, J. D. Novak, \& J. Vanhear (Eds.), CMC2012. Concept Maps: Theory, Methodology, Technology. Proceedings of the Fifth International Conference on Concept Mapping. (pp. 180-187). Malta. Retrieved from http://cmc.ihmc.us/cmc2012papers/cmc2012-p123.pdf

Darder, A., Pérez, A., \& Salinas, J. (2014). Análisis de usos del mapa conceptual en la investigación. In P. R. M. Correia, M. E. I. Malachias, A. J. Cañas, \& J. D. Novak (Eds.), Concept Mapping to Learn and Innovate. Proceedings of the Sixth International Conference on Concept Mapping.CMC2014 (pp. 31-38). Santos (Brazil): University of Sao Paulo, Institute for Human and Machine Cognition. doi:10.13140/2.1.3842.5609

De la Cruz, J. (2009). En busca de hábitos científicos: La tutoría en un doctorado en educación. In $X$ Congreso Nacional de Investigación Educativa (pp. 1-11). Veracruz. Retrieved from http://www.comie.org.mx/congreso/memoriaelectronica/v10/pdf/area_tematica 11/ponencias/0197-F.pdf

España. Real Decreto 99/2011, de 28 de enero, por el que se regulan las enseñanzas oficiales de doctorado. Boletín Oficial del Estado, 10 de febrero de 2011, núm. 35, Sec. I, pág. 13909.

Ewing, H., Mathieson, K., Alexander, J. L., \& Leafman, J. (2012). Enhancing the Acquisition of Research Skills in Online Doctoral Programs: The Ewing Model. MERLOT Journal of Online Learning and Teaching, 8(1), 34-44. Retrieved from http://jolt.merlot.org/vol8no1/ewing_0312.pdf

Gardner, S. K. (2009). The Development of Doctoral Students: Phases of Challenge and Support. ASHE Higher Education Report, 34(6), 1-127. doi:10.1002/aehe.3406

Gatfield, T. (2005). An Investigation into PhD Supervisory Management Styles: Development of a dynamic conceptual model and its managerial implications. Journal of Higher Education Policy and Management, 27(3), 311-325. doi:10.1080/13600800500283585

Green, P., \& Bowden, J. (2012). Completion mindsets and contexts in doctoral supervision.Quality Assurance in Education, 20(1), 66-80. doi:10.1108/09684881211198257

Gurr, G. M. (2001). Negotiating the "Rackety Bridge” - a Dynamic Model for Aligning Supervisory Style with Research Student Development. Higher Education Research \& Development, 20(1), 81-92. doi:10.1080/07924360120043882

Hernández, F., \& Díaz, E. (2010). La formación de doctores en el contexto del EEES. Una formación basada en competencias. Revista Fuentes, 10, 69-82. Retrieved from http://www.doredin.mec.es/documentos/00820113011964.pdf

Hilmer, M. J., \& Hilmer, C. E. (2011). Is it where you go or who you know? On the relationship between students, Ph.D. program quality, dissertation advisor prominence, and early career publishing success. Economics of Education Review, 30(5), 991-996. doi:10.1016/j.econedurev.2011.04.013
Holley, K. A., \& Lee, M. (2012). The challenges of designing and implementing a doctoral student mentoring program. Innovative Higher Education, 37(3), 243253. doi:10.1007/s10755-011-9203-y

Jaeger, A. J., Sandmann, L. R., \& Kim, J. (2011). Advising Graduate Students Doing Community-Engaged Dissertation Research: The Advisor-Advisee Relationship. Journal of Higher Education Outreach and Engagement, 15(4), 525. Retrieved from http://openjournals.libs.uga.edu/index.php/jheoe/article/view/626/480

Le, Q. (2012). E-Portfolio for enhancing graduate research supervision. Quality Assurance in Education, 20(1), 54-65. doi:10.1108/09684881211198248

Lee, A. M. (2007). Developing effective supervisors: concepts of research supervision. South African Journal of Higher Education, 21(4), 680-693. Retrieved from http://epubs.surrey.ac.uk/492/1/fulltext.pdf

Lee, A. M. (2008). How are doctoral students supervised? Concepts of doctoral research supervision. Studies in Higher Education, 33(3), 267-281. doi:10.1080/03075070802049202

Lee, A., Dennis, C., \& Campbell, P. (2007). Nature's guide for mentors. Nature, 447(7146), 791-797. doi:10.1038/447791a

Lee, A., \& Green, B. (2009). Supervision as metaphor. Studies in Higher Education, 34(6), 615-630. doi:10.1080/03075070802597168

Mainhard, T., van der Rijst, R., van Tartwijk, J., \& Wubbels, T. (2009). A model for the supervisor-doctoral student relationship. Higher Education, 58(3), 359373. doi:10.1007/s10734-009-9199-8

Maxwell, J. M. (2009). Contesting the Culture of the Doctoral Degree: Candidates' Experiences of Three Doctoral Degrees in the School of Education, RMIT University. RMIT University. Retrieved from http://researchbank.rmit.edu.au/eserv/rmit:6738/Maxwell.pdf

McKenney, S., \& Reeves, T. C. (2012). Conducting Educational Design Research. New York: Routledge.

McKenney, S., \& Visscher-Voerman, I. (2013). Formal education of curriculum and instructional designers. Educational Designer. Journal of the International Society for Design and Development in Education, 2(6). Retrieved from http://www.educationaldesigner.org/ed/volume2/issue6/article20/pdf/ed_2 6 _I SDDE_SMcK_IV_13.pdf

Overall, N. C., Deane, K. L., \& Peterson, E. R. (2011). Higher Education Research \& Development Promoting doctoral students' research self-efficacy: combining academic guidance with autonomy support. Higher Education Research \& Development, 30(6), 791-805. doi: $10.1080 / 07294360.2010 .535508$

Plomp, T. (2013). Educational Design Research: An Introduction. In T. Plomp \& N. Nieveen (Eds.), Educational Design Research (pp. 11-50). Enschede, the Netherlands: SLO. Netherlands institute for curriculum development.

Reeves, T. C., McKenney, S., \& Herrington, J. (2011). Publishing and perishing: The critical importance of educational design research. Australasian Journal of Educational Technology, 27(1), 55-65. Retrieved from http://ascilite.org.au/ajet/ajet27/reeves.html

Rodríguez, R. M. (2011). Repensar la relación entre las TIC y la enseñanza universitaria: problemas y soluciones. Profesorado. Revista de currículum y formación del profesorado, 15(1), 9-22. Retrieved from http://www.ugr.es/ recfpro/rev151ART1.pdf

Salinas, J. (2009). Innovación educativa y TIC en el ámbito universitario: Entornos institucionales, sociales y personales de aprendizaje. In II Congreso Internacional de Educación a Distancia y TIC. Lima, Perú. Retrieved from http://gte.uib.es/pape/gte/sites/gte.uib.es.pape.gte/files/Lima-salinas.pdf

Salinas, J. (2010). Innovación docente y uso de las TIC en la enseñanza universitaria. In Jornada Integración TIC en la Docencia Universitaria. Santiago de Chile (Chile). Retrieved from http://gte.uib.es/pape/gte/publicaciones/innovaciondocente-y-uso-de-las-tic-en-la-ensenanza-universitaria

Salmon, G. (2012). E-Moderating: The Key to Teaching and Learning online (Third Edit.). New York: Routledge.

Sánchez, C., \& Castellanos, A. (2013). Las competencias profesionales del tutor virtual ante las tecnologias emergentes de la sociedad del conocimiento. EDUTEC. Revista Electrónica de Tecnología Educativa, 44. Retrieved from http://edutec.rediris.es/Revelec2/Revelec44/pdf/Edutec-e_n44-SanchezCastellanos.pdf

Sánchez, M., Manzano, N., Rísquez, A., \& Suárez, M (2011). Evaluación de un modelo de orientación tutorial y mentoría en la Educación Superior a distancia. Revista de Educación, 356, 719-732. doi:10-4438/1988-592X-RE-2010-356119

Shacham, M., \& Od-Cohen, Y. (2009). Rethinking PhD learning in corporating communities of practice. Innovations in Education and Teaching International, 46(3), 279-292. doi:10.1080/14703290903069019

Strang, K. D. (2009). Measuring online learning approach and mentoring preferences of international doctorate students. International Journal of Educational Research, 48(4), 245-257. doi:10.1016/j.ijer.2009.11.002 
Tapia, E., Rivera, E., \& Piantzi, L. (2013). Estudio exploratorio de creencias acerca de la redacción y supervisión de tesis. RIDE. Revista Iberoamericana para la Investigación y el Desarrollo Educativo, 10. Retrieved from http://www.ride.org.mx/docs/publicaciones/10/experiencias_innovaciones_ped agogicas/D67.pdf

Tejedor, F. J., García-Valcárcel, A., \& Prada, S. (2009). Medida de actitudes del profesorado universitario hacia la integración de las TIC. Comunicar, 33(XVII), 115-124. doi:10.3916/c33-2009-03-002

van den Akker, J. (2013). Curricular Development Research as Specimen of Educational Design Research. In T. Plomp \& N. Nieveen (Eds.), Educational Design Research (pp. 53-70). Enschede the Netherlands: SLO. Netherlands institute for curriculum development.

Vilkinas, T. (2007). An Exploratory Study of the Supervision of Ph.D./Research Students' Theses. Innovative Higher Education, 32(5), 297-311. doi:10.1007/s10755-007-9057-5

Vilkinas, T., \& Cartan, G. (2001). The behavioural control room for managers : the integrator role. Leadership \& Organization Development Journal, 22(4), 175185. doi:10.1108/01437730110395079

Zeegers, M., \& Barron, D. (2012). Pedagogical concerns in doctoral supervision: a challenge for pedagogy. Quality Assurance in Education, 20(1), 20-30. doi:10.1108/09684881211198211 